\title{
A MÁQUINA DE JOSEPH WALSER, DE GONÇALO M. TAVARES E A MODALIZAÇÃO DO VAZIO
}

\author{
JOSEPH WALSER'S MACHINE, BY GONÇALO M. TAVARES AND \\ THE MODALIZATION OF EMPTINESS
}

Ibrahim Alisson Yamakawa'

\begin{abstract}
RESUMO:AmáquinadeJoseph Walser, deGonçaloM.Tavares, objetobasedas discussōes empreendidas neste artigo, faz um retrato da crise da sociedade tecnocrática, ao por em tela Joseph Walser, um dedicado operário de fábrica que se abdica de si mesmo em favor da máquina para sobreviver à violência decorrente da guerra e da máquina . Em decorrência disso, Joseph Walser passa por um processo de esvaziamento de sentidos acelerado pelo ritmo implacável das máquinas e pela violência da guerra. Logo, a convivência com o vazio torna-se inevitável. É fato, portanto, que para este romance o vazio demonstra ser um eixo de extrema significaçăo. Assim, o presente artigo propóe uma reflexăo sobre a modalizaçâo do vazio nesse romance, especialmente, aquele caracterizado pela falta e o que se apresenta enquanto possibilidade de sentido. Para auxiliar essa reflexăo, recorre-se aos estudos de Santiago Kovadloff (2003), David Le Breton (1991); (2018), entre outros.
\end{abstract}

Palavras-chave: A máquina de Joseph Walser; Gonçalo M. Tavares; vazio.

ABSTRACT: Joseph Walser's Machine, by Gonçalo M. Tavares, object of the discussions undertaken in this article, gives a picture of the crisis of technocratic society, as Joseph Walser, a dedicated factory worker who abandons himself in favor of the machine to survive the violence of war and machine. As a result, Joseph Walser undergoes a process of emptying of the senses accelerated by the relentless pace of machines and war. Therefore, coexistence with emptiness becomes inevitable. It is a fact, therefore, that for this novel emptiness proves to be an axis of extreme significance. Thus, the present article proposes a reflection upon the representation of emptiness in this novel, especially that characterized by the lack and by the one that presents itself as a possibility of meaning. To support this reflection, Santiago Kovadloff (2003), David Le Breton (1991); (2018), among others are evoked.

Keywords: Joseph Walser's Machine; Gonçalo M. Tavares; emptiness.

1 Doutorando no Programa de Pós-Graduaçăo em Letras da Universidade Estadual de Maringá (UEM). E-mail: ibrahimalisson@gmail.com 
Permanecem praticamente inexploradas as ocorrências do(s) vazio(s) no campo dos estudos literários. Ainda que a ideia de vazio já tenha sido abordada por filósofos, por psicanalistas, entre outros, faltam aos estudos literários pesquisas que tratem das ocorrências, dos efeitos e das motivaçôes do(s) vazio(s) em textos literários. Pois, nâo raro, para poetas e romancistas o vazio é objeto de apropriaçăo criativa e de modalizaçâo na literatura. $O$ vazio é para a literatura um eixo de extrema importância e significaçăo. Apesar de só se fazer conhecer obliquamente, ou seja, permanecer uma interrogaçăo em torno dele, como se ele fosse parcialmente vedado e encoberto à compreensáo e à leitura plena, o vazio, em A máquina de Joseph Walser, de Gonçalo M. Tavares comprova ser uma instância decisiva à leitura e à análise para a compreensăo do romance.

Dito isso, escrever sobre vazio em A máquina de Joseph Walser, de Gonçalo M. Tavares consiste em um desafio teórico-analítico em funçăo dos escassos trabalhos realizados pelos estudos literários em torno desse tema. A isso ainda se acrescente o fato de que os trabalhos protagonizados, especialmente, pela filosofia e pela psicanálise no intuito de abranger o vazio mostraram-se inesgotáveis e infindáveis. Embora cada área, à sua maneira, tenha empenhado incontáveis esforços tentando abranger o vazio em toda sua complexidade, por intermédio de diferentes perspectivas, esses campos do conhecimento, ao final, acabaram inevitavelmente dispersando a concepçáo do vazio. Por isso, o estudo do vazio no campo literário prescinde de defini-lo e circunscrevê-lo no texto. Ao contrário, os estudos literários diante do vazio devem elucidar as suas formas de enunciaçăo, os efeitos de sentido e suas causas no texto literário e lidar com o fato de que o estudo do vazio na literatura năo significa tentar preenche-lo com significados e traduzi-lo com palavras, pois o vazio de um sentido e a falta de uma palavra é, necessariamente, a presença de outros sentidos e um convite ao silêncio.

Diante dessas consideraçôes, o presente trabalho tem como escopo abordar as ocorrências do(s) vazio(s) presente(s) em A máquina de Joseph Walser, de Gonçalo M. Tavares, identificando as causas desse(s) vazio(s), bem como os efeitos de sentido causados por essa ausência que se impóe enquanto presença. E de fato, A máquina de Joseph Walser é um candidato bastante adequado para esse objetivo, pois nesse romance, o vazio torna-se uma questăo central ao por em tela a desumanizaçăo, a indiferença e a violência da sociedade tecnocrática, uma vez que ele lança luz sobre vazio e o processo de esvaziamento que caracteriza as personagens, especialmente a protagonista.

A máquina de Joseph Walser é o segundo romance da série intitulada O Reino, publicado em 2004, por Gonçalo M. Tavares. Como nos demais romances que compôe a série, a guerra, a violência e a indiferença sâo temas de destaque. O romance conta a história do operário de fábrica, Joseph Walser, obcecado pela precisăo técnica, pela máquina e por sua coleçăo única de peças metálicas. Operário diligente, ele esforça-se para manter o ritmo da máquina com que trabalha e fazer crescer a sua coleçăo de peças, apesar da guerra e das atrocidades que o cercam. Adepto da cultura tecnocrática, Joseph Walser prima pela exatidăo, no sentido mesmo da técnica, e, por isso, mantem uma vida disciplinada ajustada ao ritmo da máquina com que trabalha. Com efeito, percebe-se que a técnica desumanizou-o, fazendo-o agir como máquina, porém como uma máquina em disfunçăo e inferior, que busca incessantemente pela peça metálica perfeita, como que para consertar o que ele sente que está errado e preencher o seu vazio. 
Estava, pois, Joseph Walser, constantemente em frente ao inimigo [a máquina]; mas sendo eficaz, manifestando permanentemente a sua atençăo exacta, Joseph conseguia, dia a pós dia, ano após ano, manter esse inimigo a uma distância tal que acabava por o considerar, afinal, um amigo. (TAVARES, 2010, p. 21).

Assim, a "amizade" que Joseph Walser tem por sua máquina é um misto de fascínio e de medo. "Joseph Walser sentia-se, de facto, observado por ela, pela 'sua' máquina" (TAVARES, 2010, p. 21), como um superior que observa um subordinado. Para atender às expectavas dela, ele abdica-se de si mesmo afasta-se cada vez mais da sua relaçấo com o próximo e com o seu próprio eu. De tal forma, que ele converte-se em "máquina" e torna-se emocionalmente indiferente ao caos que o rodeia. Com efeito, a sensaçấo de vazio experimentada por esta personagem torna-se paradoxalmente devastadora e libertadora.

Diz-se devastadora, no sentido de que, essa sensaçăo figura, primeiramente, como "privaçăo de sentido e realidade, ao passo que, na verdade, parece que é a incompreensível plenitude do sentido e da realidade" (KUHN, 1949, p. 10-1) 2. À medida que a realidade se desintegra diante da violência da guerra, Joseph Walser sofre esse processo de perda de sentido e, como consequência, experimenta uma "paralisia total" diante do caos que se instala e, que se apresenta de forma tâo dramática, que só faz aumentar a sensaçăo de vazio reinante. Ao mesmo tempo, enquanto o vazio que se abre diante da personagem é caracterizado pelo horror em funçâo da perda de sentido das coisas e da solidâo do outro e de si mesmo, o vazio é, simultaneamente, a possibilidade de um sentido transcendente. ${ }^{3}$

Assim, a partir de A máquina de Joseph Walser, de Gonçalo M. Tavares, espera-se discorrer sobre o(s) vazio(s) representado(s) no romance. Acredita-se que tal presença aponta, primeiramente, para a falta, ausência e privaçăo de conteúdo, e, ao mesmo tempo, a experiência dramática que a personagem tem com o vazio configura-se como expressáo de profundidade, capaz de descentralizar o homem-máquina e restituir a sua humanidade. Trata-se de um vazio que "năo se pode ser afirmado, nâo se pode dizer que seja, e por isso, é um meio de questóes năo respondidas" (KUHN, 1945, p. 31). Em outras palavras, o vazio pode ser entendido como substantivo do homem, uma instância indizível, que a técnica năo pode alcançar, e cujo valor inestimável está associado à angústia de ser, propriedade exclusiva do homem.

2 "Nothingness is the privation of meaning and reality, whereas, in truth, it seems to me that it is the incomprehensible fullness of meaning and reality" (KUHN, 1949, p. 10-1, traduçáo nossa).

3 "Literalmente transcendência significa 'atravessar' ou 'ultrapassar'. Aquilo que é ultrapassado no movimento da transcendência é, de acordo com a metafísica tradicional, o mundo sensível ou a natureza, e o objetivo do movimento é Deus. Heidegger faz o mesmo termo significar a passagem da existência além de si mesmo para outros objetos além de si mesmo. Assim, ela se torna intimamente ligada à ideia de projeçăo, e deve seguir a curva reflexiva desse conceito gêmeo. Ou seja, o objetivo do movimento transcendente năo está no mundo dos objetos, mas no eu. A existência que transcende a si mesma atravessa o mundo para retornar para si mesmo" (KUHN, 1945, p. 143, traduçăo nossa). O vazio enquanto possibilidade de sentido transcendente é caminho para compreender as profundezas do sujeito, para descobrir o que estava encoberto ou o que se ignorava. O sujeito consciente de seu próprio vazio năo ignora a parte mais profunda de si mesmo. Quem se descobre vazio nele encontra-se a si mesmo e ativa a percepçăo do silêncio primordial, que se caracteriza por "uma ausência originária: a que impede que o homem se sinta totalizado" (KOVADLOFF, 2003, p. 45).

4 "Nothingness cannot be affirmed it cannot be said to be; therefore the array of unanswered questions" (KUHN, 1945, p. 31, tradução nossa). 
Dessa forma, muito para além do vazio enquanto ausência de conteúdo causado pela exacerbaçáo da técnica e da frieza da máquina, o vazio é impreterivelmente possiblidade de sentido transcendente. Sob esse ponto de vista, podem-se distinguir duas instâncias de vazio, cada qual com seus significados e efeitos. Para cumprir os objetivos até aqui elencados convocam-se para este estudo, entre outros autores, Santiago Kovadloff (2003), David Le Breton (1991); (2018) e Helmut Kuhn (1945).

Deve-se compreender desde logo que o vazio é uma palavra que enuncia uma conceituaçăo complexa, mas que por ser também uma palavra de uso corrente, sua definiçâo torna-se mais "solta", de modo que nem sempre a sua concepçăo é clara. O termo vazio pode remeter, entre outras coisas, a ideia de algo que nada contém; desabitado; desprovido; falto; vácuo; e até mesmo algo fútil e frívolo (XIMENES, 2000). O vocábulo vazio tem origem latina, vacivus, "que significa literalmente falta de conteúdo" (TEIXEIRA, 2008, p. 11). De acordo com Maria Lúcia Homem, "um outro sentido para a palavra ancora-se na parcela vaz e significa 'desprovido, destituído de', ou seja, vazio como prova de ausência: algo foi retirado e em seu lugar encontra-se o vácuo" (HOMEM, 2005 , s/p). Vazio é, portanto, a falta de algo que pode ser potencialmente preenchido e, ao mesmo tempo, aquilo que nada contém, mas que năo necessita, necessariamente, de complemento.

O vazio está, portanto, associado à ideia de que năo encerra nada, logo, designa o nada. No limite, o vazio é indeterminado e indeterminável. É indeterminado porque năo contém conteúdo nem substância, é falto de resoluçăo; e é indeterminável no sentido de năo se pode defini-lo, por nele um fim, ou seja, ele năo é passível de ser, algum momento no futuro, determinado. O vazio é, pois, indefinível e inefável. Trata-se de ponto de vista enigmático, uma vez que essa noçăo exclui a própria perspectiva de preenchê-lo. O vazio é, em certo sentido e paradoxalmente, a renúncia de conteúdo em particular para náo renunciar a qualquer conteúdo em geral e ser, pois, sentido transcendente. E é justamente por essa característica que o vazio adquire especial relevância para os estudos literários.

Em Atlas do corpo e da imaginaçâo, por exemplo, Gonçalo M. Tavares escreve que: "o que nunca termina de ser respondido é o essencial" (TAVARES, 2012, p. 27). O escritor ainda prossegue: "eis o que interessa: rodear o que năo tem fórmula, o que ainda nâo tem soluçăo [...] o que nunca terá soluçăo" (TAVARES, 2012, p. 28). Diante das palavras do autor, é possível afirmar que ele tem, pois, interesse, entre outras coisas, pela modalizaçăo do vazio. Tanto que em A máquina de Joseph Walser, por exemplo, há a manifestaçăo do vazio de uma experiência e do vazio que é constitutivo e constituidor do homem, que se afirma indeterminável e irresoluto, mas que se apresenta enquanto propriedade e substância inalienável do ser.

Pode-se distinguir, portanto, duas instâncias de vazio representadas no romance: o primeiro é determinado a ser preenchido, caracterizado por uma ausência, por uma falta, por um -1, pela privaçăo e carência de significaçóes disponíveis. O segundo é caracterizado por uma ausência radical e esvaziamento intransponível. Em outras palavras, trata-se do inatingível. De acordo com Santiago Kovadloff, esse vazio é aquele que se percebe enquanto presença inalienável, e, năo enquanto ausência. “Olhando sem ver, chamamos Invisível; escutando sem entender, o designamos Inaudível; tocando-o sem atingi-lo, o chamamos de Imperceptível" (KOVADLOFF, 2003, p. 113). Essa instância de 
vazio năo trata do que propriamente năo existe, mas do que existe e năo se é capaz de abordar em toda sua extensăo.

A despeito de haver um vazio sem conteúdo caracterizado por uma ausência, por uma falta, por um -1, ele ainda é experienciável, isto é, ele náo deixa de ser examinado, observado e interpretável. Até mesmo o vazio năo deve aceitar-se sem exame, porque, como bem lembra Maurice Merleau-Ponty "A ausência de signo pode ser um signo" (MERLEAU-PONTY, 1992, p. 44). Isto é, a falta de um sentido confirma a possibilidade de múltiplos sentidos, nâo pela sobreposiçâo e substituiçâo de um sentido por outro, mas pela coexistência de múltiplos sentidos que potencialmente podem significar a partir de um signo ausente.

Por isso, se se admitir que o vazio possa ser falto de algo, nâo se deve limitar-se a questionar, por exemplo: é falta de quê? Porque os sentidos produzidos pela privaçâo de conteúdo, prescindem do objeto ausente, ou seja, năo é necessário reaver ou recobrar aquilo que foi perdido para compreender o vazio, até porque, no limite, isto năo é mais possível, entretanto, faz-se necessário, senăo primordial, ressignificar essa perda observando as flutuaçōes de sentido sempre pendentes. Helmut Kuhn defende que a ausência de um signo fornece a pista para outros signos possíveis conferindo, portanto, um semblante de positividade a uma negatividade (KUHN, 1945). Logo, o vazio caracterizado pela privaçăo significa mesmo enquanto ausência de signos disponíveis.

Recorrendo às palavras de Santiago Kovadloff, “o vazio [...] dista de ser mera negaçăo de presença. É presença de outra índole [...] năo é necessariamente o que năo existe [...] ao contrário, o que só percebemos como ausência" (KOVADLOFF, 2003, p. 113). A ausência mencionada por ele nâo deve ser entendida como ausência redutora de significados. E nesse ponto, é importante ressaltar a diferença entre o vazio com a marca do menos e o vazio que se faz notável enquanto presença primordial. Porque para Maria Lúcia Homem, o vazio como falta é um indicativo da "possiblidade de" (possibilidade disto ou daquilo, ou seja, significaçóes pendentes e disponíveis), que para essa autora, nâo se confunde com o inominável (HOMEM, 2005).

De maneira complementar, Santiago Kovadloff entende que o vazio de uma carência "poderia ser dito alguma vez" (KOVADLOFF, 2003, p. 9), porque ele se trata de "ocultaçăo ou negaçấo do que, no final das contas, seria possível explicitar [...]" (KOVADLOFF, 2003, p. 9). Isto é, trata-se, pois, de um vazio que se apresenta, de antemáo, como frágil e efêmero que se enraíza em terreno tangível e se interpóe entre o sujeito e o objeto ausente. Este vazio alimenta a expectativa de que, eventualmente, poderá ser definível e preenchível.

Cria-se a ilusáo de que assim que se descobrir o elemento faltante e ou as causas de sua ausência o vazio estará superado. Entretanto, o vazio de uma carência é uma noçăo cambiante que muda conforme as circunstâncias. De tal forma que o homem tenta em văo preencher aquilo que somente é parcialmente reconhecível. E a busca de significado é simultaneamente negaçăo de outros significados possíveis. Embora tangível e verbalizável por ser ausência de significaçōes disponíveis, é também, por essa mesma razáo, irresoluto e indefinível, pois a definiçăo de qualquer coisa implica na exclusâo de quaisquer outras significaçôes disponíveis. Em suma, se fosse possível satisfazer o vazio de tudo seria impossível reconhecer o vazio em qualquer coisa.

O vazio inominável, por outro lado, ainda segundo Santiago Kovadloff, "[...] só percebemos enquanto ausência [...]" (KOVADLOFF, 2003, p. 113). Este pode ser reconhecido, 
mas "năo pode ser alcançado" (KOVADLOFF, 2003, p. 10). O inominável que caracteriza o sujeito năo tem nada de encoberto; ele é, pois, uma presença incontestável e irredutível além de seu meio, porém sem ser inexpressável. E ainda que inacessível à palavra, năo deixa de significar. O inominável é uma instância instransponível que sempre permanecerá, em certa medida, ignoto e repleto de reservas para as quais a sua apreensâo total será, definitivamente, impossível e inapreensível, o que sustenta a ilusâo de que ele é vedado à compreensăo por nâo estar disponível à explicitaçâo, quando, na verdade, é significaçâo de outra natureza, ou seja, sentido-vazio; silêncio primordial.

O vazio em questâo nâo significa, portanto, nihil ou simplesmente o nada, mas uma instância radiante de significaçōes que năo é constituída de sentidos verbalizáveis, mas "[...] silêncio extremo do qual o seu próprio nome é apenas umbral, pórtico aberto ao insondável" (KOVADLOFF, 2003, p. 167), que se desdobra diante do sujeito. Segundo Santiago Kovadloff, a experiência com o vazio é perceber-se diante desse "horizonte inescrutável, quase sempre encoberto pela necessidade imperiosa de escapar da angústia da própria contingência" (KOVADLOFF, 2003, p. 121). Para explicar essa condiçăo, o autor ainda recorre à obra de Martin Heidegger, que diz que existir significa reconhecer-se dentro desse nada que năo é nem positivo e nem negativo, mas que aciona a percepçáo de uma presença e de uma ausência. Martin Heidegger acredita que "Existir (exsistir) significa: estar sustentando-se dentro do nada (...)" (HEIDEGGER, apud KOVADLOFF, 2003, p. 48). Existir, para ambos os autores, significa reconhecer-se como parte desse vazio e reconhecer o vazio como parte de si próprio. Talvez, esse reconhecimento pudesse acionar a percepçăo da existência e por sua excepcional intensidade ele poderia suprir uma carência de imagem e permitir ao homem o reconhecimento de si mesmo diante de seu próprio vazio. Em síntese, o homem é resguardado no próprio vazio e o inominável se resguarda no interior do próprio homem.

Assim, diante da possibilidade de o vazio significar tanto pela carência e pela falta como quanto pela presença de um sentido-vazio e silêncio primordial, espera-se confirmar a hipótese de que o vazio, acelerado pela violência da técnica e da guerra, significa enquanto "possibilidade de" e que o vazio que se manifesta no silêncio primordial é expressâo de profundidade, capaz de descentralizar Joseph Walser "o homem-máquina" e restituir a sua humanidade. Acredita-se que a incursăo no romance de Gonçalo M. Tavares, assinalará duas instâncias de vazio, cada qual com suas características e com seus efeitos de sentido que se confirmarâo fundamentais à leitura e à compreensăo de A máquina de Joseph Walser.

É particularmente significativo que as primeiras linhas de A máquina de Joseph Walser descrevam um "homem estranho" (TAVARES, 2010, p.9), que enquanto veste as calças, diz à esposa: "Claro que os humanos eram materiais que pensavam!" (TAVARES, 2010, p. 9). Necessário efeito do ponto de vista acima expresso, é a ideia de que homens e máquinas (materiais) se confundem ao ponto de ser, em essência, a mesma coisa.

Na epígrafe que se lê "o espanto da semelhança", de Maria Filomena Molder5, a

5 "O espanto da semelhança" faz eco em outra obra de Gonçalo M. Tavares intitulada Breves notas sobre as ligaçōes. Nesta obra, o autor retoma essa expressâo de Maria Filomena Molder e discute sobre o que significa ser um colecionador. Joseph Walser é um colecionador e nas palavras de Maria Filomena Molder, "(os colecionadores) [sáo] « movidos pela expectativa de encontrar » (MFM)" (TAVARES, 2012, p. 267). Ser colecionador é estar em uma busca, de certa maneira, constante, para preencher vazios com objetos 
apropriaçáo das palavras da autora preenche o vazio da narrativa diante de uma relaçâo que o leitor perceberá inenarrável e, portanto, vazia. A mençăo à semelhança póe em relevo a obscura relaçâo da personagem com a máquina, que é em última análise a motivaçăo de sua experiência com o vazio. A segunda epígrafe, por sua vez, é mais direta sobre essa relaçăo: "Ele bem queria rezar a oraçâo, mas só era capaz de se lembrar da tabuada", de Hans Christian Andersen. O que está proposto é a falência da resistência ou da oposiçăo à reificaçăo para existir como humano.

Ambas as epígrafes traduzem a ideia da técnica como substituiçăo parcial ou mesmo total do ser humano. Ideia que se complementa quando no início do romance se lê que: "Materiais com alma, diria mesmo Margha" (TAVARES, 2010, p. 9). A imagem da máquina se confunde com a imagem do humano, com a única diferença de que esta possui alma. Atributo faltante na máquina e uma distinçăo frágil se se levar em estrita consideraçăo a personagem protagonista.

Joseph Walser é um operário de fábrica que age como máquina, e tudo em sua rotina é absolutamente ajustado ao ritmo implacável dela, o que explica a sua convicçâo sobre a semelhança entre o homem e a máquina. Esse homem "vestia umas calças simples, quase de camponês, e os seus sapatos castanhos estavam absolutamente fora de moda" (TAVARES, 2010, p.9). Na opiniâo de sua esposa: "Estás vestido como noutro século. Já ninguém pensa assim" (TAVARES, 2010, p. 9). Em suma, está inadequado tanto na forma de se vestir quanto na de se pensar. Um homem que se considera máquina vivendo entre homens, consequentemente, sente-se desajustado, incompatível e inadequado. Por isso, a personagem protagonista adota uma postura vazia e evasiva, ou seja, de mudez e de esvaziamento completo.

Klober Muller - o encarregado da fábrica onde Walser trabalhava - declara: "Você nâo perde tempo meu caro, tem aquilo a que se pode chamar 'instinto da utilidade', um instinto que lhe permite afastar-se precisamente do desperdício, do excesso. Você é um homem exacto Walser" (TAVARES, 2010, p. 156). Muito embora, caiba ressaltar que o "instinto da utilidade" citado por Klober Muller sobre Joseph Walser nâo se materializa, uma vez que a personagem que "năo perde tempo" năo é retratada exercendo sua atividade na fábrica. Ao contrário, as vezes que a personagem está diante da máquina da fábrica a açâo é suspensa em favor da discussāo sobre a relaçâo entre homem, técnica e máquina. A realizaçâo do trabalho em si é esvaziada e cede espaço às divagaçôes ou do narrador ou do encarregado. A personagem também se esvazia por completo, isolando-se em casa com a sua coleçáo única de peças metálicas ou entretendo-se com o corriqueiro jogo de dados na casa de colegas.

Joseph Walser é absolutamente indiferente. Năo porta documentos e, por isso, recebe uma reprimenda de alguém năo enunciado pelo narrador em um espaço nâo definido, ou seja, espaço e tempo se dissolvem e o vazio sobrescreve as instâncias narrativas. Nessa parte, lê-se que: "Joseph Walser năo traz documentos. Alguém diz: estes dias nâo săo para distracçôes, săo necessários documentos. Joseph Walser recebe a reprimenda em silêncio" (TAVARES, 2010, p. 10). Em tempo de guerra, crê-se passar

da mesma natureza. "Colecionar é ligar as coisas pelas suas semelhanças [...] o colecionador é obcecado pelas semelhanças [...]" (TAVARES, 2012, p. 268). Mas năo apenas isso, o colecionador é obcecado em ocupar espaços "vazios" com as peças que ele coleciona e também pela sua identificaçáo com o objeto colecionado como é o caso de Joseph Walser. 
despercebido, afinal, supōe-se máquina; máquina em meio a homens.

Com efeito, o vazio de identificaçăo da personagem aprofunda a sua relaçấo com uma das formas de vazio abordada pelo romance: vazio da ausência e da carência de imagem e de sentido. Por isso, opta por silêncio. "Walser era um homem estranho, falava pouco" (TAVARES, 2010, p. 19). Entretanto, a maneira de estar em silêncio dele difere do silêncio atencioso, do bom ouvinte, muito pelo contrário, a postura da personagem é de completo emudecimento.

Em funçăo disso, frequentemente questiona-se: “Meu caro Joseph Walser, estará mesmo a ouvir-me - era-lhe perguntado vezes sem conta. O rosto de Walser denotava um alheamento geral constante" (TAVARES, 2010, p. 19). Joseph Walser cala para omitir-se, para nâo emitir qualquer sentido. A personagem renuncia opiniōes, julgamentos, avaliaçōes de quaisquer tipos e adota uma atitude absolutamente indiferente e vazia. Levando em consideraçăo o esvaziamento produzido por ela em funçâo do seu comportamento silente, é possível traçar uma paralelo com o que escreve David Le Breton: "a indiferença ao mundo e aos outros poupa qualquer investimento, mas expóe ao vazio [...] o indiferente cria uma universo único para si, autossuficiente" (LE BRETON, 2018, p. 38), mas apenas em aparência.

De modo que, o alheamento extremo é consequência do sentimento de colapso e do seu autoaprisionamento no vazio, o qual torna o sujeito incapaz de "ir além da estreiteza imposta por aquilo que chamamos habitualmente de 'nós mesmos"' (KOVADLOFF, 2003, p. 177). Ao invés de se entregar a um silêncio capaz de permitir que se "reconheça em sua condiçáo básica de carente" (KOVADLOFF, 2003, p. 49), Joseph Walser nega essa carência pela incapacidade de nomear aquilo que lhe falta.

O "gerenciamento" das relaçôes com as demais personagens é fruto do horror ao vazio do inominável. Com efeito, a dificuldade da personagem em compreender esse vazio invisível, inaudível e imperceptível que lhe fala, o leva a esvaziar-se de si mesmo e refugiando-se em sua coleçăo. O vazio, rapidamente, no caso de Joseph Walser, transforma-se em esvaziamento, vazio em negativo e enquadra-se como radicalizaçăo do processo de reificaçăo e, por conseguinte, promove o anulamento do outro e o seu próprio autoanulamento.

A mudez da personagem constrói em volta dela uma fortaleza vazia, cuja única funçáo é blindar e apartar a personagem dos acontecimentos do mundo exterior e ao mesmo tempo de seu próprio interior. A realidade exterior tornou-se insuportável para a personagem: guerra, violência, trabalho extenuante etc.. Nâo obstante, ela também năo buscou refúgio dentro de si, para năo se encontrar com o seu próprio vazio. Ao invés, ausentou-se de si mesmo e ficou indiferente a todos ao seu redor. Sobre isso, destaca-se a seguinte passagem:

Ele sim era um grande Homem, um Homem, como defendia Klober, que conseguia estar separado de todos os outros, um homem verdadeiramente sozinho e individual. Porque precisamente os seus actos pareciam nâo ter qualquer ligaçăo às outras pessoas, como se estas náo existissem. Estavam separados: ele e os outros; os seus actos eram independentes, autônomos, e esta era a sua grandeza. (TAVARES, 2010, p. 129). 
David Le Breton escreve que "o indiferente pôe uma espécie de vidraça entre ele e o mundo, um muro invisível, para năo ser atingido por um acontecimento [...]"(LEBRETON, 2018, p. 39). O alheamento constante da personagem corresponde a um recurso para se poupar da violência exterior e do vazio sem sentido que a rodeia. Apesar disso, o fechamento sobre si mesmo expōe Joseph Walser ao seu próprio vazio. Entretanto, a incapacidade de poder lidar com essa instância de si que é, de antemáo, inominável e irreversível, torna a personagem indiferente a ela própria. E tal incompreensăo configura-se como peça chave para compreensâo do vazio romance.

Em um mundo povoado pela máquina e regido segundo a lei da máquina e da técnica, conviver com o seu próprio vazio e com o seu silêncio interior parece impossível. E quanto mais a técnica obriga o homem a refugiar-se dentro de si mesmo, menos o homem consegue lidar com o seu vazio. E tal sensaçâo fortalece em seu íntimo o seu desejo de tornar-se máquina e superar de todo modo o vazio que lhe é inerente. "O alheamento constante em relaçâo às conversas e a estranheza de alguns dos seus comportamentos tinham, definitivamente, a mesma origem. A sua coleçâo [...]" (TAVARES, 2010, p.81) de peças metálicas, que se explica pelo fato de a personagem querer encontrar entre essas peças a peça que lhe falta e converter-se em máquina.

O superior de Joseph Walser na fábrica o alerta que: "As máquina de guerra vêm aí, mas nâo tenha medo. $O$ problema náo săo as máquinas que se aproximam da cidade, săo as máquinas que já aqui estăo" (TAVARES, 2010, p. 15). A disparidade fundamental que caracteriza a relaçăo entre homem e máquina reside no fato de que, quaisquer que sejam as máquinas, elas superaram o ser humano. Esse "é o grande espanto do século" (TAVARES, 2010, p. 17). De acordo com Klober Muller: "ser feliz já náo depende de coisas que vulgarmente associamos à palavra Espírito. Depende de matérias concretas. A felicidade humana é um mecanismo" (TAVARES, 2010, p. 17). Assim, a confrontaçăo entre máquina e homem é absolutamente marcada por dissonâncias perpétuas. "As máquinas interferem na História do país e também na nossa biografia individual" (TAVARES, 2010, p. 15). Resulta do que foi exposto que a nova posiçáo ocupada pela máquina na história inspira o vazio em Joseph Walser. Segundo Klober Muller, o homem foi destituído de tudo em favor da máquina. À máquina tudo e a Joseph Walser nada.

Assim, "quanto mais intensidade existia no corpo, mais fácil era afastar-se, ser testemunha de si próprio" (TAVARES, 2010, p. 124). Quanto mais dedicado à máquina, menos ele se dedicava a si mesmo. De tal modo que Joseph Walser se projetava para fora de si mesmo, longe do seu vazio interior. Ver-se de longe "[...] quando a intensidade dos sentimentos era quase nula. Se ele já lá náo estava - na existência - como se poderia ainda mais afastar?" (TAVARES, 2010, p. 124). A resposta para ele tornou-se simples: converter-se, absolutamente, em máquina.

Estava, pois, Joseph Walser, constantemente em frente ao inimigo [a máquina]; mas sendo eficaz, manifestando permanentemente a sua atençăo exacta, Joseph conseguia, dia a pós dia, ano após ano, manter esse inimigo a uma distância tal que acabava por o considerar, afinal, um amigo. (TAVARES, 2010 p. 21, grifo nosso).

Pelo exposto, evidencia-se o processo de reificaçăo da personagem protagonista. Enquanto trabalha operando a máquina precisa mostrar, sem qualquer hesitaçăo, constância, eficácia, permanência e atençăo exata em tudo que faz. Características 
próprias de uma máquina. Com efeito, a máquina - sua inimiga - torna-se sua amiga ao final. "Joseph Walser sentia-se, de facto, observado por ela, pela 'sua' máquina" (TAVARES, 2010, p. 21), como um superior que observa um subordinado, cumprindo exatamente as funçóes que lhe foram atribuídas. O operário tentava corresponder às expectativas dela como se ela o avaliasse.

Joseph Walser faz agora um pequeno intervalo, afastando-se da sua máquina que quase o sufoca depois de duas horas seguidas de esforços [...] Joseph Walser envelhece, mas mantém a adoraçáo pela 'sua' máquina de trabalho e por todos os mecanismos. Em diversos momentos o som do motor e o seu trepidar confundem-se com o bater cardíaco, pois ambos os 'órgáos' estăo em pleno funcionamento, em plena excitaçăo, e encostados um ao outro misturam-se, provocando em Walser, por vezes, sobressaltos ridículos quando, a horas certas, às horas exactamente planeadas, o motor da máquina subitamente cessa. E é aí que Walser percebe a ligaçăo que existe entre o seu corpo e a máquina (TAVARES, 2010, p. 53).

Năo pode existir reciprocidade entre o homem e a máquina se ambos têm dissimilitudes irreparáveis, mas Joseph Walser năo percebe isso quando está operando a "sua máquina". A insistência da personagem em chamá-la de "sua", como se ela, de fato, pertencesse a si ou fosse parte de si, confunde mais a relaçấo que ele tem com a máquina da fábrica. À medida que a personagem desumaniza-se em prol da máquina esta, por sua vez, personifica-se. A personagem doa seu coraçăo à máquina e "em diversos momentos o som do motor e o seu trepidar confundem-se com o bater cardíaco, pois ambos os 'órgáos' estăo em pleno funcionamento" (TAVARES, 2010, p. 53). O motor de metal transforma-se em órgâo e o coraçăo rende-se ao ritmo e à velocidade da máquina.

A ligaçâo entre Walser e a máquina encerra um duplo aspecto: a personificaçâo da máquina parece concorrer com o processo de reificaçăo da personagem protagonista: uma troca assimétrica. Em coerência com a impossibilidade de ele reconhecer-se humano, Walser demonstra dificuldade no reconhecimento da máquina enquanto máquina (coisa). Além disso, o vínculo que ele procura construir entre ele e a máquina está ligada ao desejo da personagem de que ela (a máquina) torne-se o "ser" que o libertará do vazio que é expressâo máxima de humanidade. E diante disso, o vazio enquanto possibilidade de transcendência torna-se, gradativamente, o vazio do retirado, do ausente. Cada vez que a máquina cessava:

\begin{abstract}
Walser năo morria, isso tornava-se para ele evidente um segundo depois de cada paragem [...] $\mathrm{O}$ organismo de Walser ficava, quase se poderia dizer, melancólico, no momento em que o motor parava e ele percebia que estavam ali, em jogo, afinal, duas coisas: ele e a máquina. Duas coisas incompatíveis, separáveis, duas coisas que se podiam afastar. E a melancolia vinha desta evidência [...] (TAVARES, 2010, p. 54).
\end{abstract}

E em concomitância com a atitude de Joseph Walser, Klober Muller, explica que “[...] a ciência individual por excelência, no limite, quer eliminar todas as outras existências, porque as odeia [...]" (TAVARES, 2010, p. 119). E o que se percebe é que o comportamento de Walser espelha esse conjunto de valores. E em virtude disso, Joseph Walser era: 
[...] um homem verdadeiramente sozinho e individual. Porque precisamente os seus actos pareciam nâo ter qualquer ligaçáo às outras pessoas como se estas náo existissem. Estavam separados [...] Já estou preparado para năo amar ninguém - e esta frase dita assim, para si próprio, era sentida como a sua grande arma em tempo de guerra, a grande defesa em relaçăo à agressividade do século [...] năo possuía qualquer inclinaçấo para o amor ou para a amizade. (TAVARES, 2010, p. 129-0).

Entretanto, apesar de manifestar claramente o seu desejo de se anular e de se afastar de todos, "conseguir distanciar-se do mecanismo que o constitui năo faz o mecanismo deixar de existir" (TAVARES, 2010, p. 128), ou seja, afastar-se de si mesmo como que para se afastar do vazio que lhe é inerente năo faz com que o vazio simplesmente deixe de existir, porque, em um primeiro momento, este vazio năo é privaçăo, mas consiste justamente de uma realizaçăo fundamental da existência.

Decorre desse afastamento a evidencia ainda maior do vazio existente entre as coisas: "[...] todas as coisas entre si se podiam afastar" (TAVARES, 2010, p 54). Joseph Walser comprovava tal consideraçāo fazendo uma pequena experiência: "Aproximavase de uma das mesas de trabalho, encostadas a uma parede, e puxava-a, como que a querer sentir a força que separar exige e, ao mesmo tempo, o fácil que é fazer esse acto" (TAVARES, 2010, p. 54). Embora desnecessário o gesto foi o suficiente para Walser perceber como poderia suprimir o vazio.

Gonçalo M. Tavares escreve que "as ligaçôes săo diminuiçóes de liberdade, eis uma ideia antiga: a indiferença como sinônimo de liberdade [...]" (TAVARES, 2012, p. 129) e, neste caso, de superaçăo do vazio. Negar qualquer vínculo com o mundo ao seu redor para permanecer suspenso fora da existência, significa, paradoxalmente, ser carente de tudo e ao mesmo tempo, náo pertencer a nada, ou seja, significa libertar-se do vazio inerente às ligaçôes e às aproximaçōes. Ao propor um afastamento definitivo entre ele e as coisas, explica David Le Breton que "o indivíduo está desligado, indiferente, mas continua presente sem se sentir obrigado a participar" (LE BRETON, 2018, p. 33). Com isso, em resposta ao vazio inominável, o qual náo poderia superar sem suprimir sua própria existência, uma vez que sua disposiçáo absoluta se afirma na própria existência, Joseph Walser provoca, năo sem consequências, uma carência.

Primeiro, afastar-se do outros, ser carente do outro: "quanto mais a desordem e a imprevisibilidade da guerra aumentavam mais Walser se refugiava no seu escritório" (TAVARES, 2010, p. 82). Segundo David Le Breton, "é possível enclausurar-se na própria casa ou fazer o próprio apartamento um mosteiro [...]" (LE BRETON, 2018, p. 22). Depois, afastar-se da máquina:

Joseph Walser recomeçou naquele dia, após a breve interrupçăo das dezasseis horas, o seu trabalho, colocando o corpo ao longo da máquina para o recomeço dos gestos [...] o peito de Walser pousava verticalmente sobre uma peça metálica ligeiramente desconfortável na sua parte mais inferior [...] as máos estavam já nos locais próprios da máquina, encaixando de modo exacto e permitindo apenas os gestos necessários à funçâo. De repente, a máo escorregou ao longo da máquina e, destacando-se de todos os outros ruídos da fábrica, um enorme grito saiu da boa do funcionário Joseph Walser. (TAVARES, 2010, p. 55). 
A ruptura se dá tanto entre a personagem e a máquina quanto na própria narraçăo. O capítulo e a primeira parte do romance terminam subitamente sem enunciar o que teria acontecido à personagem. "Tinham-lhe amputado o dedo indicador" (TAVARES, 2010, p. 75) da măo direita. Joseph Walser nunca mais trabalharia junto da "sua" máquina novamente. Năo havia mais ligaçăo entre ele e a máquina da fábrica. A prova do vazio tornava-se entâo certeza da falta de um dedo e do seu distanciamento em relaçâo à máquina. A sensaçăo de vazio era suportável porque reconhecível e denominável, diferentemente do vazio que o constitui enquanto homem.

Joseph Walser fecha-se sobre si mesmo, evita sair de casa. “Queres ficar sozinho? - perguntou Margha. Walser náo respondeu" (TAVARES, 2010, p. 73). Na sala em que guardava os objetos de sua coleçấo ele encarava a sua mâo: "com o livro de anatomia aberto, Joseph Walser pousou de novo as măos na mesa e abriu-as [...] Sentiu entăo um terror, como se estivesse a olhar para as măos de um monstro" (TAVARES, 2010, p. 78). A falta do dedo indicador da máo direita materializava o vazio do retirado.

A incapacidade da personagem em lidar com o vazio indizível da sua existência fez com que provocasse um vazio reconhecível senăo pela presença, mas pela falta. Tal é o vazio que alimenta a expectativa de que eventualmente poderá ser recobrado, criando a ilusâo de que conhecendo o(s) elemento(s) faltante(s) - o dedo indicador da máo direita e o seu afastamento definitivo da "sua" máquina - decorrência da amputaçâo em funçâo do acidente, poderia, em algum momento, superá-los.

Os olhos pareciam ainda obcecados pelo espaço deixado vazio pelo dedo indicador, porém, a măo comportava-se, aparentemente, como um grupo que se houvesse organizado, de modo interno, para continuar a cumprir sua missăo [...] Desde o primeiro momento em que vira aquele espaço absurdo no sítio onde antes estava o seu dedo indicador, que percebera que seus dedos eram coisas como quaisquer outras; a sua máo inteira era uma coisa como qualquer outra, uma coisa separável de si, exatamente como a régua e a peça metálica. (TAVARES, 2010, p. 79-0).

Aliás, por um tempo, "Walser sentia que alguém, ou algo, lhe havia roubado nâo apenas uma parte do corpo, mas movimentos [...] haviam-lhe roubado possibilidades de movimento; numa palavra: vontades" (TAVARES, 2010, p. 92). Apenas com a sua coleçăo é que ele se sentia "apaziguado" (TAVARES, 2010, p. 94) como se as peças de sua coleçâo compensassem a falta do dedo. É verdade que por um certo tempo, Walser desejou retornar ao seu antigo posto na fábrica. "Joseph Walser sentia apenas falta da 'sua' máquina. Era a ausência do contacto diário com esse mecanismo que relembrava a amputaçâo sofrida" (TAVARES, 2010, p. 89). Tendo perdido o dedo, também perdera o direito de operar a máquina. A sensaçăo de vazio que tomou Joseph Walser, no entanto, se bastava com a sua coleçăo.

Enquanto registrava mais uma peça para coleçăo Joseph Walser olhou fixamente para: "a peça metálica, a sua măo esquerda, a sua máo direita e a régua [...]" (TAVARES, 2010, p. 79) e se convenceu de que seu dedo amputado năo era indispensável. Ele - Joseph Walser - "funcionava" perfeitamente bem sem o dedo indicador da măo direita, mas sabia que as peças de sua coleçâo eram indispensáveis ao mecanismo a que pertenciam.

As peças metálicas que ele reunia tinham o potencial de "interferir na guerra" 
(TAVARES, 2010, p. 100), diferentemente de dedo indicador. Pensava que cada peça que ele possuía era uma arma a menos no conflito se esta pertencesse a uma arma. "Este pensamento deu a Walser um enorme prazer. Se aquela peça pertencia a uma arma, pequena ou grande, essa arma náo estaria agora a funcionar [...]" (TAVARES, 2010, p. 99). Assim, "o espaço vazio do seu dedo já năo perturbava minimamente o olhar. Era como se a măo tivesse nascido assim, com ele" (TAVARES, 2010, p. 98). A falta de um dedo àquela altura năo tinha qualquer relevância.

O que náo se pode dizer que a personagem acostumara-se à deficiência na máo direita, embora soubesse que o vazio que se materializava na falta de um dedo era irremediável, porém, era preferível ao "vazio inevitável com o qual tropeça o seu desejo de alcançar inteira elucidaçăo" (KOVADLOFF, 2003, p. 45), sabendo que essa dimensâo do vazio ele jamais poderia suprimir. Logo, a sua amputaçăo e, consequentemente, o afastamento da máquina da fábrica eram decorrências de "um homem exacto" (TAVARES, 2010, p. 156). Pode-se dizer de uma falha calculada.

Quando Walser encontrou um cadáver na calçada com máos perfeitas e completas "passou-lhe pela cabeça isto: [...] ele podia rapidamente roubar a măo direita ao morto, leva-la, e trocar depois pela sua. Para que quer ele todos os dedos se está morto?" (TAVARES, 2010, p. 132). Entretanto, tal pensamento foi substituído pela conclusâo de que "aquele homem estava morto; já năo se encontrava à sua frente, apesar de apenas a poucos centímetros" (TAVARES, 2010, p 133). Por que roubar alguém ou algo que já năo está presente? Seria como roubar do próprio vazio. "Walser baixou-se e começou a desapertar o cinto" (TAVARES, 2010, p. 134). Roubou a fivela do cinto do cadáver, pois ele constatara antes que ela era indispensável ao objeto ao qual pertencia, diferentemente das máos daquele cadáver.

Era como se sua coleçâo tivesse um novo propósito: criar ausências tomando uma peça indispensável ao mecanismo. Se, de fato, Joseph Walser năo poderia superar definitivamente a sua condiçâo de carente, poderia, por sua vez, promover o vazio nas máquinas. A máquina o esvaziara, ele esvaziaria as máquinas recolhendo peça por peça e guardando junto às demais de sua coleçăo.

O final do romance registra o fim da guerra, a volta da normalidade, "o tempo passara" (TAVARES, 2010, p. 154) e "năo parece ser Joseph Walser" (TAVARES, 2010, p. 147). Finalmente testemunhara o fim da guerra e repetia: "acabou e estou vivo! Como se estranhamente estar vivo pudesse ser o final de alguma coisa" (TAVARES, 2010, p. 146). O fim do esvaziamento de si mesmo? Chegara, portanto, o fim de ver-se de longe? "Conseguimos, Joseph" (TAVARES, 2010, p. 146) acrescentou Margha. O que se pode depreender dessa passagem é o "esforço" empreendido por essas personagens para sobreviver à guerra como se tudo o que fizeram até esse momento fosse reflexo do instinto de sobrevivência: ser vazio para se proteger e para sobreviver.

Na última cena, Joseph Walser está só com Klober Muller. O protagonista é absorvido pelo monólogo da outra personagem que expressa o seu ódio pelo humano: "tenho até um certo nojo da matéria humana, devo confessar" (TAVARES, 2010, p. 160) e aos poucos, revela o seu ódio por Joseph Walser. Klober Muller responsabiliza Walser por ter abandonado a sala de máquinas, por ter deixado de ser um mecanismo eficiente e constante na fábrica, para se tornar um mecanismo preguiçoso: 
Abandonou-nos, sabe, caro Joseph Walser? Foi para outro sítio e deixou-nos aqui, sozinhos, com as máquinas. Já reparou: está a ouvir? Estăo a funcionar. Exactamente. Ao domingo e a funcionar. Todas. Liguei-as, năo é extraordinário? Os motores funcionam ao domingo. Mas năo foi para lhe falar da preguiça de alguns mecanismos que o chamei hoje aqui (TAVARES, 2010, p. 155).

E, atrevendo-se ir mais além, Klober Muller desaprova todo o comportamento de Walser durante de guerra: o alheamento constante, como se estivesse desligado dos acontecimentos, năo se envolvendo com a guerra: "sei que năo participou da guerra, fez bem em afastar-se, tal como eu, diga-se" (TAVARES, 2010, p. 156), fazendo-o parecer "de um outro mundo, de um outro século" (TAVARES, 2010, p. 159). Cabe reportar que as palavras de Klober Muller se contradizem. Segundo ele, "atraiçoei um ou outro homem - sei que alguns talvez tenham sido fuzilados com o meu contributo ou, pelo menos, com a minha falta de memória abrupta [...]" (TAVARES, 2010, p. 160). Registre-se, portanto, que "insistia Klober -, os factos năo se passaram como sâo contados" (TAVARES, 2010, p. 117). É importante considerar essa declaraçăo da personagem uma vez que suas palavras estăo aquém de suas verdadeiras intençōes. Walser compreendera que o que Klober dizia sobre a grandeza era falso.

O monólogo prossegue: "Você é um homem de paz, sem dúvida" (TAVARES, 2010, p. 160); "Eu sou seu amigo, espero que finalmente o perceba. Você merece viver, Walser, e năo ei dizer melhor frase a um homem [...]" (TAVARES, 2010, p. 162). Quando, na verdade, Walser era um homem que, no seu entendimento năo merecia viver. Klober Muller considerava-o um covarde. Dizia ele que: "Os outros, os que fogem para a montanha ou para a floresta, nâo sâo solitários mas cobardes. Tanto como os que náo saem de casa até que a guerra acabe" (TAVARES, 2010, p. 119). Assim, trancados à chave no escritório, dariam início à derradeira guerra:

[...] a última guerra, a verdadeira, a que se afastará desta imitaçâo, será aquela e que cada um combaterá todos os outros, em que cada homem será o início e o fim do seu exército; a guerra verdadeira, a guerra exacta, a guerra que demonstrará finalmente o que é um indivíduo, essa guerra, que ainda năo veio, que jamais se viu em qualquer ponto, mas que verá, estou certo, essa guerra é aquela onde, qualquer dois corpos que se aproximem o faráo por ódio. Toda aproximaçăo será para matar, ou ainda náo estaremos perante verdadeiros Homens. (TAVARES, 2010, p. 120).

Com uma pistola carregada com apenas um cartucho, o jogo de dados de decidiria quem levaria o tiro daquela arma. Havia muita provocaçâo da parte de Klober Muller: "seria uma grosseria exigir que disparasse sobre mim com uma mâo deformada. Estaria a exibir a sua deficiência, esse buraco" (TAVARES, 2010, p.161). Para ele, era inconcebível ser executado por um homem com duas măos fracas (a máo deficiente e a mâo esquerda). "Nunca o dedo indicador da sua măo fez tanta falta como hoje. Maldita amputaçăo, meu amigo" (TAVARES, 2010, p.161). Ele também acrescentara que: "náo roubaria a felicidade de quem anda por aí só para que viesse testemunhar o meu suicídio" (TAVARES, 2010, p. 159). Precisamente este último ponto é de extrema relevância, pois há indícios no monólogo de Klober Muller que ele năo pretende cometer suicídio: "ainda năo decidi nada, estou a aqui a falar consigo porque realmente ainda nâo decidi" (TAVARES, 2010, p. 159). Para ele, ser morto por outro faria mais sentido, mas nâo, 
por alguém mais fraco, como era Joseph Walser, um homem deficiente. Klober Muller năo enxergava Walser além de sua deficiência. Era, de fato, um homem inferior e covarde que teria que ser eliminado. "Toda aproximaçâo será para matar, ou ainda nâo estaremos perante verdadeiros Homens" (TAVARES, 2010, p. 120). Convencido de sua superioridade, Klober lança os dados primeiro. Os resultados favorecem-no. Joseph Walser, no entanto, permanece absorvido em silêncio.

O jogo de dados sempre fora um escape ao vazio, pois, quando jogava "sentia que controlava o mundo" (TAVARES, 2010, p. 29), "nada era desconhecido, năo havia o algo mais que perturba, o algo mais năo visível" (TAVARES, 2010, p. 26), ou seja, esquecia-se da impreterível presença vazio. Mas, na presença do encarregado o jogo era outro, tornava-se uma ameaça: o resultado decidiria ou pela vida ou pela morte. Náo por acaso, o romance reservou-se ao silêncio. Nenhuma palavra é dita quer pelo narrador quer pelo protagonista. Sabe-se, porém, que ele se prepara para lançar os dados. David Le Breton escreve que "o vencido é reduzido ao silêncio" (LE BRETON, 1991, p. 90). No último lance, o silêncio impóe-se sobre a narraçăo e prevalece o enigma da palavra ausente: o vazio.

À luz dessas reflexóes, A máquina de Joseph Walser aponta para vazio(s): o primeiro que se afirma inapreensível e irresoluto, mas que se apresenta enquanto propriedade e substância inalienável do ser e o segundo, caracterizado por uma ausência, vazio efêmero. Com o desdobramento da análise desse romance, constatou-se que quanto mais a personagem empenhou-se para preencher a sensaçáo de vazio que é referência à presença originária, maior e mais profundo ele se tornou e, consequentemente, mais rico em sentidos, pois essa instância de vazio năo implica renúncia aos sentidos, e sim uma maneira de concebê-los.

No entanto, a dificuldade da personagem protagonista em lidar com o seu próprio vazio, converteu-se um processo de esvaziamento de sentidos que é, na verdade, acelerado pela sua crença quase total e absoluta na técnica e na precisâo da máquina. Para ele, o ritmo da máquina é tomado como uma lei inevitável, cuja força prende inexoravelmente a humanidade, entăo năo cabe ele rebelar-se contra ela, mas render-se. Entretanto, render-se, nesse contexto, significa demostrar a mais absoluta competência diante da máquina; submeter-se a ela. E ao final, apesar da ruptura definitiva com a máquina a personagem demonstra a sua incapacidade de resistir para existir como humano.

\section{REFERÊNCIAS}

HOMEM, Maria Lúcia. A funçâo do vazio. In: Anais V Encontro Latino-Americano dos Estados Gerais de Psicanálise. 2005.

KOVADLOFF, Santiago. O silêncio primordial. Rio de Janeiro: José Olympio: 2003.

KUHN, Helmut. Encounter with nothingness: an essay on existencialism. Hinsdale: Henry Regenery Company. 1945.

LE BRETON, David. Do silêncio. Traduçăo de Luís M. Couceiro Feio Lisboa: Instituto Piaget, 1999. 
. Desaparecer de si: uma tentaçáo contemporânea. Traduçăo de Francisco Morás. Petrópolis: Editora Vozes, 2018.

MERLEAU-PONTY, Maurice. A linguagem indireta e as vozes do silêncio. In: Signos, Sáo Paulo: Martins Fontes, 1992. p.39-87.

TAVARES, Gonçalo M. A máquina de Joseph Walser. Sáo Paulo: Companhia das Letras, 2010.

. Breves notas sobre ciência; breves notas sobre o medo; breves notas sobres as ligaçóes (Llansol, Molder, Zambrano). Lisboa: Relógio D'Água, 2012.

. Atlas do corpo e da imaginaçâo. Alfragide: Editorial Caminho, 2013.

TEIXEIRA, Virgílio Franco de Freitas. O vazio e o buraco negro na patologia limite: um contributo da/para técnica Rorschach. 2008. Dissertaçấo (Mestrado em Psicologia Aplicada). Instituto Superior de Psicologia Aplicada, Lisboa. 2008.

XIMENES, Sérgio. Minidicionário Ediouro da língua portuguesa. São Paulo: Ediouro, 2000. 